\title{
VERNACULAR ARCHITECTURE: CHANGES IN THE TRADITION FOLKLORIC FORMS AND NARRATIONS IN OLD LEBANESE HOUSES
}

\author{
Graziella P. Daghfal Choughari \\ Assist. Professor, Notre Dame University-Louaize, Zouk Mosbeh, Lebanon, daghfal@ndu.edu.lb
}

\begin{abstract}
The vernacular houses have sustained our traditional habits and customs, which were related to the way dwellers lived, and adapted to the interior space of these houses. Although they share most of their essential characteristics, each house had its unique approach to details: location, orientation, kind of stones and woods, among many other basics used in the interior. These houses were built for a purpose, with the determination to create a shelter, to provide privacy and to establish a heaven protected by thick walls called 'kalline' and secured against danger, disaster and malicious attacks.

In a gesture of written preservation to manuscript some types of old traditional houses still existing in the country side, namely in Achkout, (my village in the heart of Keserwan, overlooking the Mediterranean Sea in Lebanon), I will document the few still-existing custom habits and household folkloric patterns, and record old and bygone stories and rituals, that are still in the memory of the very few elderlies who are still alive. My sincere effort is to try to preserve Achkout's identity, and to create awareness legacy in order to help in protecting my village identity, and to resuscitate in the hearts and minds, the curiosity and mystery of the old folkloric spaces of the 'Once upon a time' era.
\end{abstract}

Over the years, the vernacular houses were subjected to dramatic transformations, placing them on the verge of losing all relations with the old heritage and traditional ways of construction; masonry craftsmanship that required substantial group work to finish. This voluntary craftsmanship of helping hands called 'aouneh', is nowadays fading away.

The 'aouneh', free exchanging aid between the villagers, had been the ritual way of living. It had established the profound bonding between the house, its dwellers, and the rest of the village inhabitants. These architectural customs are transfigured into a mere competitive form of complicated commercial entities built on random sites spread along the country side, where the concept of 'aouneh' has ceased to exist.

Concerning the folkloric structure in building and accessorizing, every single house was unique in its details as well as its generals, from tools to foundations and partitions; 'outa-a ou aata-a'. Every detail in every house was personalized and directly related to the dwellers who occupied the interior space, and characterized it to fulfil their necessities and daily needs.

The unrestrained diffusion between the past and the present, the divergence and the intermixing between conventional customs and the old ethnic performances related to the folkloric masonry of interior spaces, could coexist.

Keywords: Household, folklore, forms, patterns, tools, tradition, customs, dwellers, masonry, construction, interior, vernacular, coexist 


\section{INTRODUCTION}

Traditional land of the Phoenicians that had been, conquered, influenced and occupied by many civilizations centuries ago, starting from the first settlements in Lebanon; Canaanites and Phoenicians (3000 - 1680 B.C.), then the conquest of Alexander the Great (333-323 B.C.), and the domination of the Seleucid Empire which lasted till 64 B.C., after which came the Romans till 395 A.D. With the end of the Byzantine Era in 634, started the dawn of the Middle Ages which lasted from 634 till 1516 A.D., the era of Arab Conquest, notably The Empires of Umayyad and the Abbasid, besides the Crusades that lasted from (1252 - 1516) and with it began the Modern Times (1516 - 1914) Ottoman Domination which divided Lebanon; 'A-ahed el Mutasarrifiyah' that ended by the famous war 'hharb el arbata-aesh', where thousands of Lebanese people in the mountains died mainly from famine. The beginning of the French Mandate paved the way to the New Lebanon to claim its of independence in 1943. Each of these civilizations and societies left behind monuments, ruins and signs spreading their existence all over the country till our present time. (Ismail A. ,1972).

Memories of the past shaped and molded our present; traces, citations and even patterns survived many generations to modify a present rich in traditions, full of folkloric forms and narrations, that are naturally integrated in our customs as part of our present daily routine.

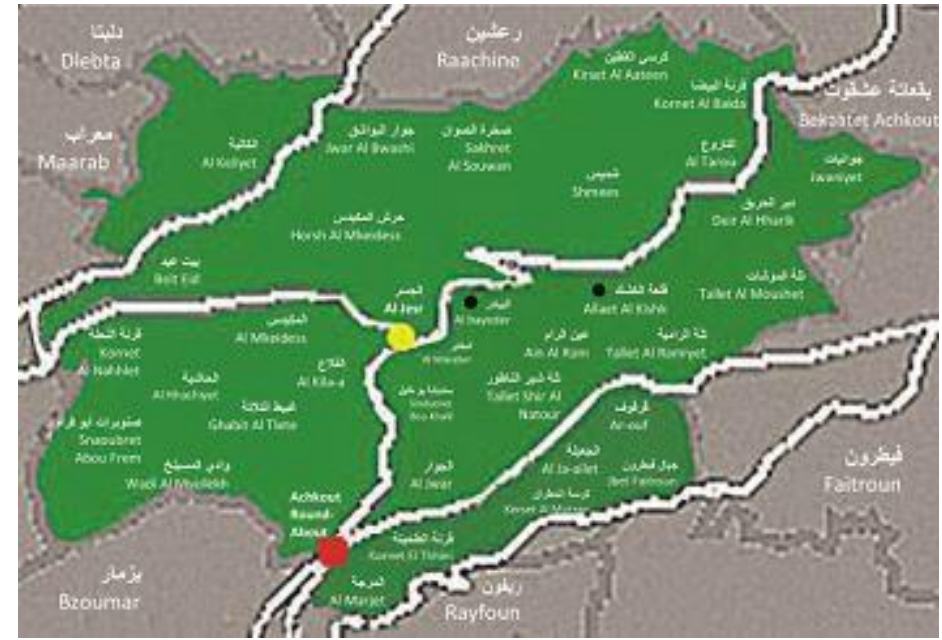

Fig. 1. Map of the old neighborhoods and regions in Achkout around which most of the vernacular houses were built.

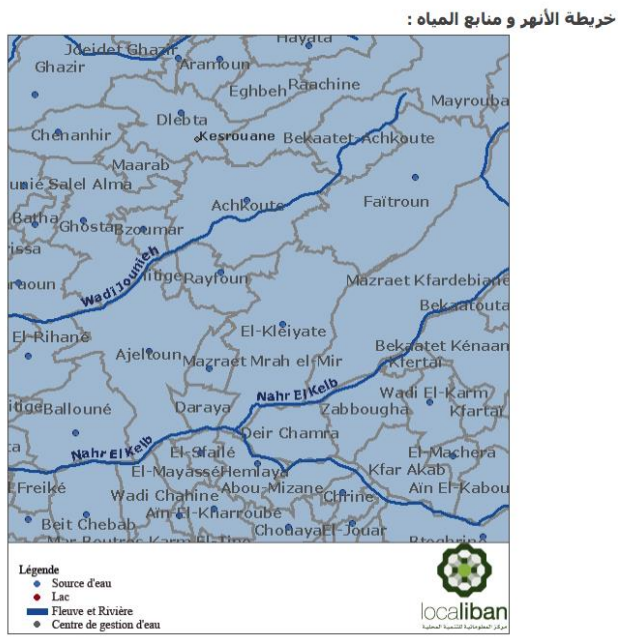

Fig. 2. In Blue; The old river that used to pass under the bridge; 'Jesr' Achkout

Achkout, my village in the heart of the stony Mountains of Keserwan, witnessed dramatic changes over the past few decades. The trend of modern transformation turned Achkout from that traditional village with its humble houses scattered among the rocks and wild trees, to this concoction of multi-cultural mix which doesn't relate, neither to our culture and ancient heritage, nor to our folkloric methods of construction and "mode de vie". The rigid and difficult nature of the land with its sloppy landscape formation, made Achkout one of the hardest places to survive and to dwell on, yet it played a very crucial role of being the roundabout of all the villages of middle Keserwan, connecting them to the main city of Jounieh; the coastal and commercial center of Keserwan.

Many stories were transmitted from one generation another about battles and oppressions in the past centuries, therefore people had to take refuge in the mountains of Achkout. The statistics that were conducted between 1933 and 2006 showed an increase from 2078 dweller in 1933, to reach 4919 in 2006 , this growth was predicted by Mr. Boulos. (Boulos,1986, p. 201).

Sheikh Albert Massaad born1926, wrote in his book, my translation in English: "......the number of houses in Achkout in the 30s was 120 houses; 41 with red brick between pointed and rectangular rooftops which was known as 'karmid el batershil', 34 among them had been ruined due to World War I, and became what we call 'khirbi'. There were three churches and plenty of wild trees outside the center of the village. Achkout was protected by three hills from South East reaching the edge of Faytroun village, and planted with vineyard and fertile trees; 'Tallet Shir Al Natour', 'Tallet Al Ramiyet' and 'Tallet Al Moushet', and the wild natural boundaries; from the East by the mountains of Faytroun, from the North 'Kirset Al Aateen', going through the middle, passing through the central mountain, 'Flintstone rock', 'Sakhret Al Souwan' going East till the steep valley of 'Wadi Al Msailekh'....", ".....it was like heaven on earth, the green mulberry trees wrapping every 
single house, and the old oak trees casting their shadow over the front-surface of these houses, 'staiihha / staiihhet el bouyout', entwining with long branched vineyards spread over the rooftops...", (Massaad, 2014, p.23)

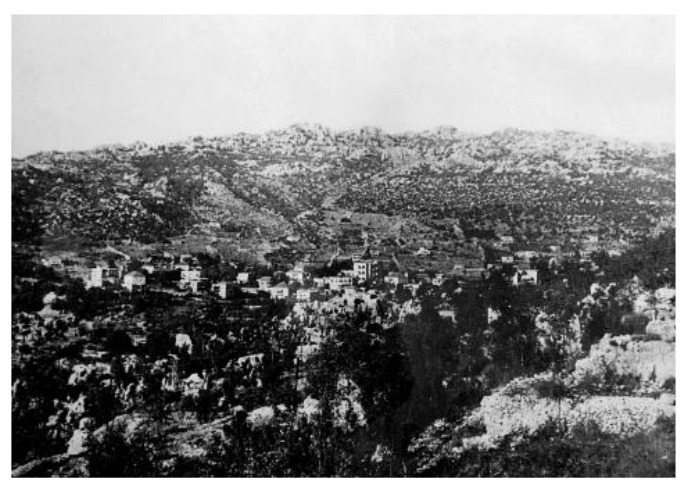

Fig. 3. Picture of Achkout in the 1940s, archive Massaad, A.

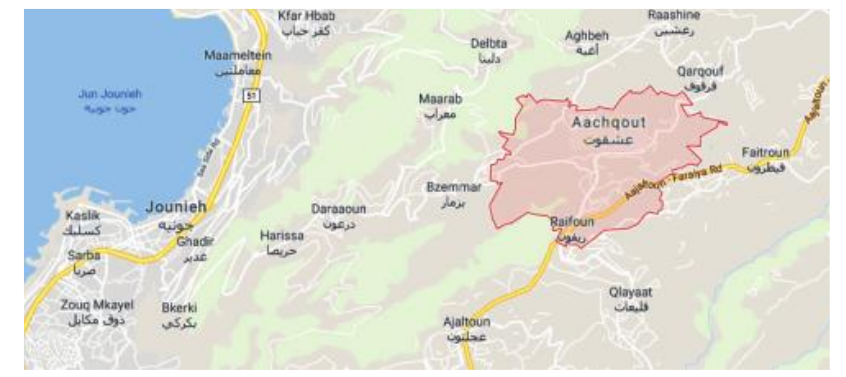

Fig. 4. Google map

Houses and buildings are now mainly constructed to be rented or sold to stranger from outside the village, and the village close community had been depleted. The vernacular houses are on the verge of losing all relations with the old heritage and the folkloric ways of domestic interactions and deeds, used to be applied in almost every household chores that were done by the use of the expression ' $a$-aouneh', which meant the act of helping and assisting one another without any compensation; exchanging aid. (Khater, 1977, p.111)

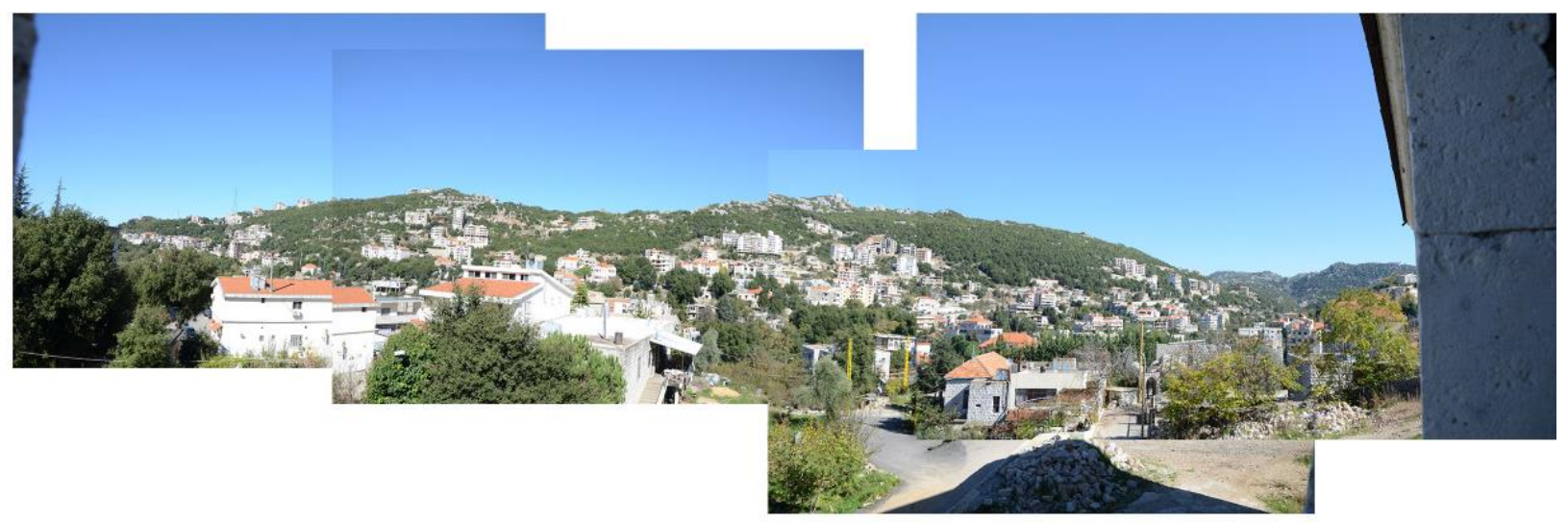

Fig. 5. Personal pictures showing the invasion of concrete, Achkout, 2018.

The fundamental transformations in the architectural folkloric approach of building houses changed dramatically since the dawn of the French mandate (1920 - 1943). These fundamental changes were integrated in both interior spaces and designs, as well as, in the exterior structural aspects of every new house to be built. The dominant fact is that technology is overcoming traditions, and all the folkloric issues are being widely advertised and applied haphazardly while disregarding the vernacular masonry designs of ancient times "...It is only in recent times that the sudden mobility within the country, the rapid development of the main cities and the acceptance of and even addiction to all western novelties, have brought about profound changes which jeopardize the survival of traditional values". (Ragette, 1974, p.12).

Besides the financial reason, the lack of know-how, and the enormous time involved in building a traditional house, the major reason in changing the technique and the method of construction is due mainly to the fact that houses and even buildings are now being commissioned to be constructed by machines, faster and less expensive, set to be sold or rented to strangers. These reasons and more, led to this irreversible fissure in the closeness of the village community, among others. (Makki, 1995, p.17).

\section{OUTER FEATURES}

\subsection{Controlled and Uncontrolled Fundamentals}

In Achkout, houses for the rich and powerful did not exist, most of the land was owner by few families where the remaining terrains were too rough and hard for anyone to dwell on comfortably. Due to these fact and 
others, namely, oppressions and persecutions, the very old traditional houses, unlike other villages at that time, were built apart from each. Each old house had its fables and stories that survived from generation to another.

The concept of a house: a home able to shelter its dwellers from natural and human oppressions a place where to hide, live and survive. These traditional houses were scattered on both sides of the three main roads known as 'Tarii Al Mkariyet', while the rest were built close to the old river that used to run through Achkout; from 'Bekaatet-Achkout' all the way down to 'Wadi Jounieh', going through 'Al Mseilekh Valley'. Modesty and humbleness were strongly reflected in every house, and their simple exterior appearances and crafty interiors used to offer both accommodation and protection. Each of these remaining houses are becoming less and less convenient and abandoned and barely noticeable in our days.

Our ancient folkloric forms, patterns, tools and designs are now fading away, turned into ruins 'Khirbi' of once-upon-a-time dwellings, and with this fact, many of our inherited habits related to those domestic behaviors will eventually vanish. Among these small crafty structural details, 'Staihha' or balcony, the first thing you notice before entering the house, 'ta-a', this small opening located below the last 'Midmek', which is the last level of stones before the thick mud ceiling, these small openings were used for ventilation, since they didn't have chimneys and all the cooking and heating had to be done inside of the houses especially in winter. Many Lebanese authors wrote about the old house with its stone-cut beauty, 'ta-asib el hhajar', namely Sheikh El Khazen (El Khazen, 1995)

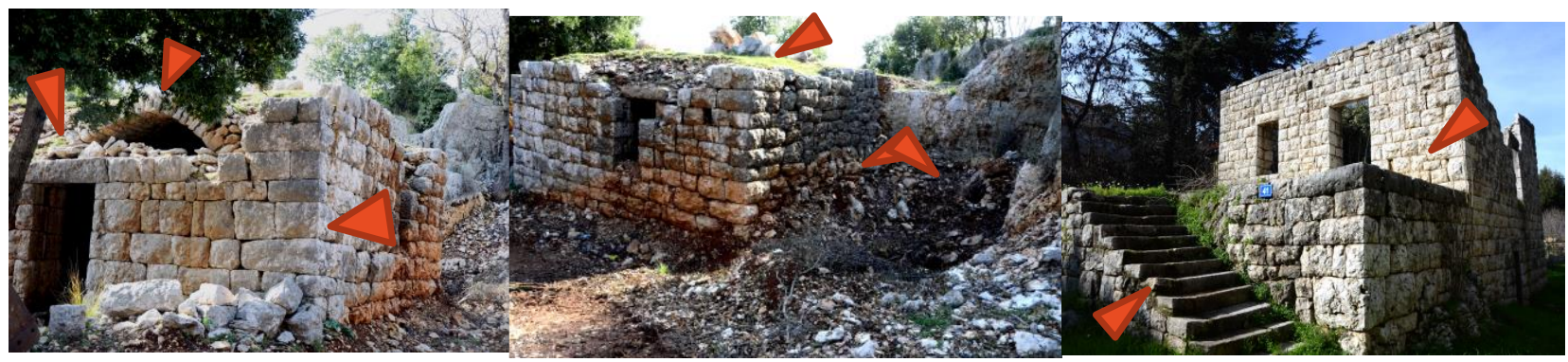

Fig. 6. My pictures of some remains of vernacular houses in Achkout showing shattered ruins or 'Khirbi', where there still exist; "A-atbet, "A-aed”, 'Midmek / madamik', 'Satehh', 'Manbesh', 'Daraj' and 'Staiihha'.

\subsubsection{Weather}

The perfect choice for building an old house was to be Incorporated in the mountain. This primarily choice was due to many reasons, mainly the short distance from the source of stones to build with, to have strong foundations, as well as a clever camouflage, making the house totally unseen, besides being able to embrace and reverse the different weather conditions, from warm and cozy during stormy winters, to cool and fresh during hot summers.

Protected by mountain cliffs and rocky reefs, these houses had the perfect component to be secured and unobserved. The fact of being scattered close to valleys and water sources, played an important role in surviving, as well as in creating the perfect leeway and escape route when threatened or attacked by anything or anyone. As time passed by, political and social aspects changed, communities began to formulate, and families were expanded, and the concept of neighborhood in Achkout, the village, was established.

There is an old Lebanese proverb: "between October and November there befall another summer", considering the Altitude, Achkout is about 1000 meters above sea level, therefore rain and snow could last for months and with the primitive means and tools, it was impossible to build houses that needed dried soil and wood in its construction process. Accordingly, the old generation of masons, always had a foremost concern; to finish the masonry work before November.

Besides the stone houses, there existed also two kinds of temporary sanctuaries: 'Khaymet' and 'Elliyet'; small shelters that were built during the summer season, on top of the main court in-front of the house.

The 'Staiihha', built on the side or even on top of the house. They both were tents made of wood and covered with branches and straws namely 'Lezzan' and 'Saikoun'; two kinds of wild grass and plants, however, the 'Elliyet' was more refined. These shelters were used between June and the 'first rain' of November since both of these accommodations provided the perfect protection from the heat, and were also 
used as cool places to sleep underneath during starry nights.

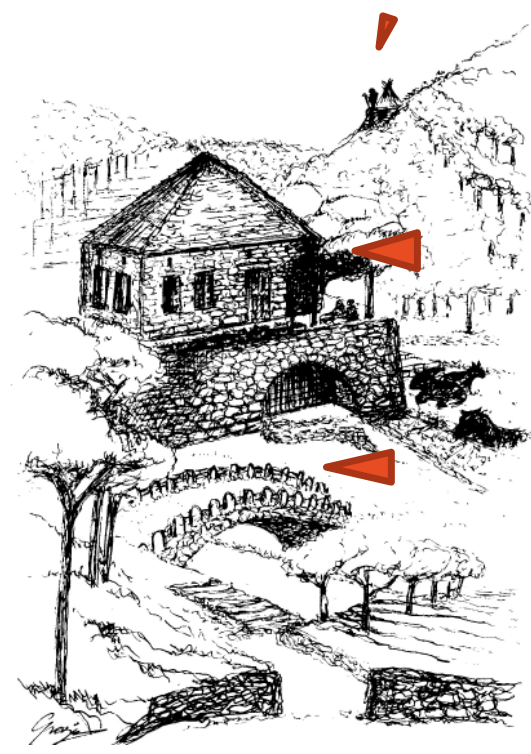

Fig. 7. My illustrations showing 'A-arzel' and 'Natour', the 'Khaymet', and 'Jisr'; bridge

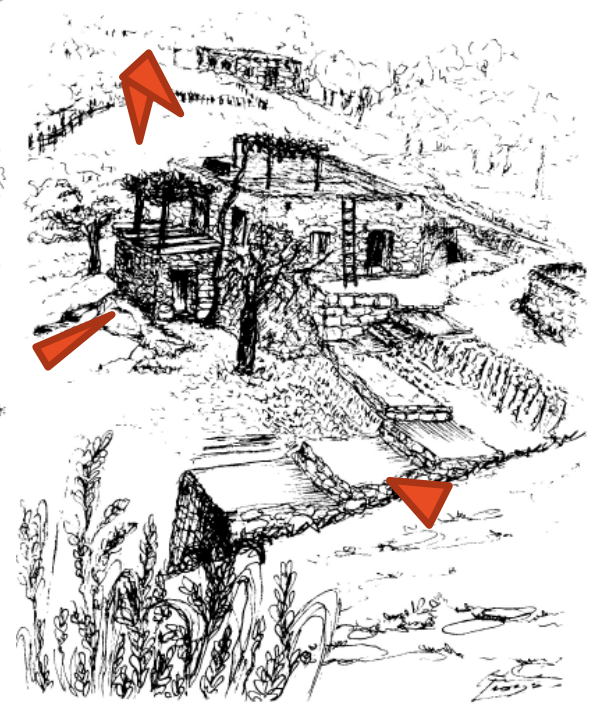

Fig. 8. showing 'Elliyet', and 'Abou' where the dwellers used to shelter their domestic animals, the 'Jal, plural Jlelet'

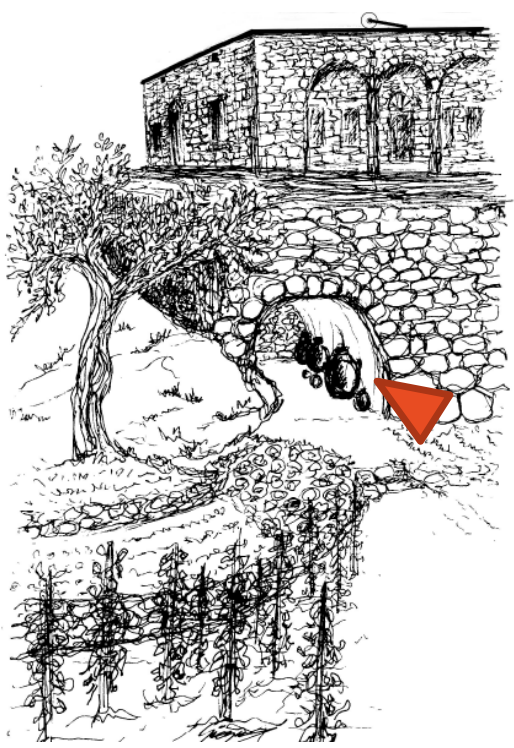

Fig. 9. showing an old three arched façade house with the 'Abou' used to store food and could be accessed directly from the house.

Another form of shelters also existed in Achkout, namely 'A-arzel'; simpler shapes of primitive and temporary formations that were built in the fields near the crops during summer. When the first inhabitants settled in the mountain of Achkout, they began looking for the good soil to be cultivated, 'rich' soil was randomly sprinkled in distant locations, some of which were far from the dwellers' houses. The time spent every day to reach fields back and forth, was avoided by building one small room called 'A-arzel' out of uncut stones 'Dabsh', and covered by trees and branches.

Since Achkout is mountainous by nature, the dwellers spent their precious time making 'Jlelet, singular Jal'; flattening the land by building steps of uncut stones or 'Dabsh', picking the gravels, plowing, planting and tending to the crops; vines, fruitful trees and vegetables. At a later stage, the 'A-arzel' was occupied by what they called, the field guard or 'Natour'; this person was very important and respected in the village, he was responsible for looking after all the fields, protecting the land from thieves and wild animals among others. (El Kassis, 2001, pp. $173-176$ )

\subsubsection{Material}

Everything that was used to build the walls, ceiling and other parts of the interior space and the exterior sections of the old houses in Achkout were made using natural, recyclable, and sustainable material that reflected their folkloric habits in preservation and respect to mother nature. The mason used only natural material in building the old traditional house; stones and gravels, wood and tree branches, soil and mud, straw and hay. The abundance of white clear rocks of the calcareous mountains of Achkout, along with the traditional know-how stone construction techniques that was firmly established since the Romans and adapted by the local masons, was reflected in the pre-dominance of pure folkloric building methods such as the vault designs. These vaults were more durable to last than the flat mud-roof houses that needed regular maintenance. The fact that timber logs needed to be imported and thus, made it more expensive to be adapted by all the local inhabitants, especially that most of the dwellers, back then, were either shepherds or farmers. (Abou Al Ainain,1980, p. 54)

The assorted and cut stones were used from the exterior side of the 'Kalline' walls; these 'Kalline' walls could reach one meter in thickness, and uncut stones 'Dabsh' from the interior. The filling between these two layers of stones was mud, hay and gravels. Every couple of stone layers, huge stones were integrated in the 'Kalline' walls called 'Rbaat', their main function is to hold and connect the two sides of the 'Kalline' wall. Finding a rock to build on; the foundation or 'Assess', was an essential matter, since everything was carried either by men or by mules or donkeys, the mason followed the method of building with large stones in the 
first rows and smaller ones as the constructed walls went up.

As for the plaster known as 'Hhouwara', it was made out of a thick layer of crashed muddy stone brought from the mountain area of Bkerki, mixed with straw and water, to be colored after that using domestic white paint; 'Kilss el hhay'; that they used to get as a result of building the traditional 'Yattoun'.

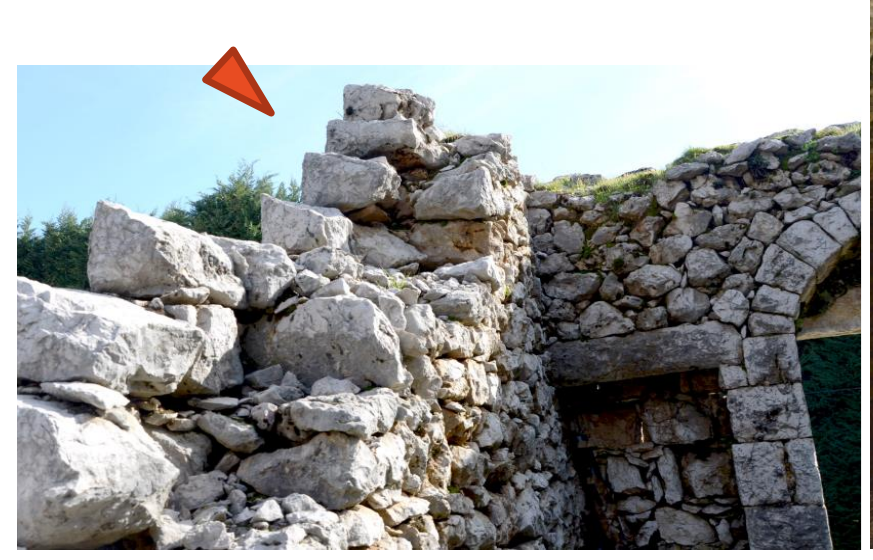

Fig. 10. My pictures showing: the 'Kalline' walls; double-stone rows, cut from the outside and uncut from the inside

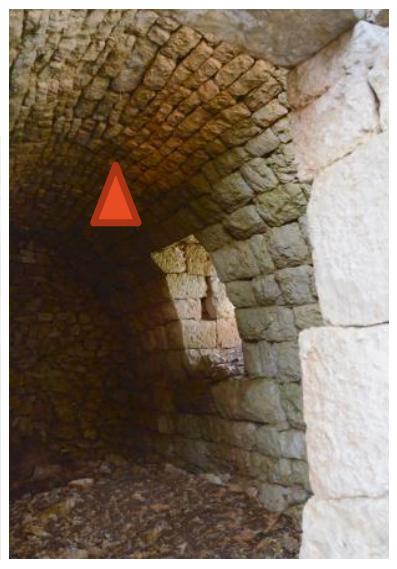

Fig. 11. Vaulted 'Abou' with curved window with a row of small key stones

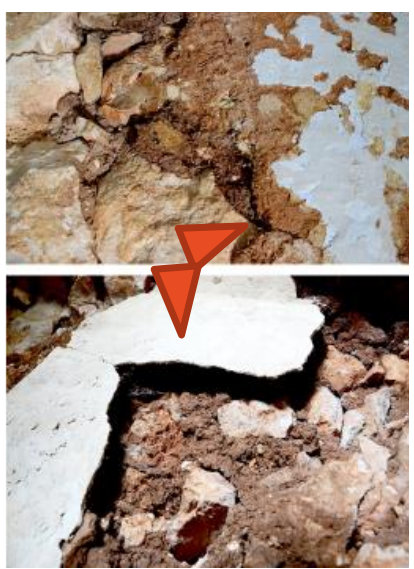

Fig. 12. Natural elements showing the thick layer of plaster and 'Hhouwara'

Large tree trunks and long wood panels were used to cover the ceiling, forming rows of straight beams supported by one or two pillars depending on the length of the house. On top of the beams, flat wood panels were laid forming a tight layer upon which a thick level of approximately $50 \mathrm{~cm}$ composed of small branches, soil and mud, pressed tightly using 'Mahhdalet'; a long cylindrical stone attached to a bended iron rod. Every-time the rain falls, the organic mixture that formed the roof, should be pressed by pulling the heavy 'Mahhdalet' all over it. Wood was also used to make doors, windows, and to manufacture some basic pieces of furniture; boxes, shelves, and closets to store food known as 'Namliyet', or "Afass" which was a wooden shell box hanging from the ceiling. The 'Afass' was used to store organic food such as meat, cheese and any left-overs, away from insects, domestic or wild animals.

Besides using clay and mud to make their kitchen tools such as plates, pans and different sizes of jars, clay was also used to cover inner walls of the fire place, called 'Maouaadet', and the walls of the 'Mastabet'.

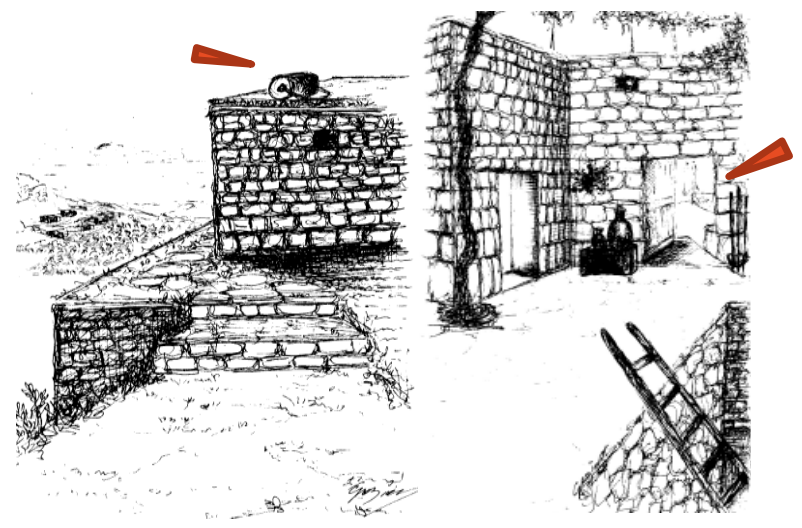

Fig. 13. 'Mahhdalet'

Fig. 14. 'Ta-at'

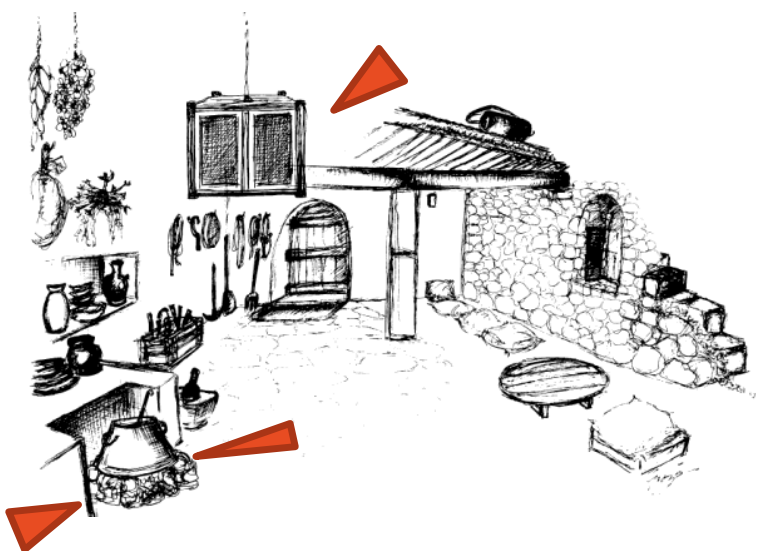

Fig. 15. 'Afass', 'Dist', and 'Maouaadet'

In their interior spaces, only the essential designs were used, minimum pieces of furniture, multifunction parts were either hanged, piled, stored all around the interior space. Everything the dwellers used in their houses was taken from nature and its richness; plants, herbs, trees, insects and animals. They used their own folkloric methods to produce the necessary utensils, appliances, tools and weapons, also they used their intuitive ways to create covers, carpets, cushions, seats, plates, pans, cups, ropes, baskets to name a few.

\subsubsection{Tools}

Depending only on themselves and their need to adapt to the wild mountain life, the first dwellers embarked 
on forming small communities and villages, and using animals as transportation means. Therefore, going to the city of Beirut was like travelling abroad, the whole village would assemble in the village square or 'Sehhit el Daia-a' for a big fair-well gathering.

To stay in the mountains and survive, the dwellers looked for shelters, and later on, houses. Everyone needed the mason, 'Ma-alem el a-amar' and the carpenter 'Nejjar'. The blacksmith or 'Hhaddad' became popular at later stages. Using hand-made tools and working with environmental material, both the mason and the blacksmith accommodated and fulfilled all the humble and the necessary domestic needs of the village, from furniture to accessories. These tools were invented and developed in order to serve the dwellers in the best possible way; either to cut, mend, shape, patch, carve and many other uses. Accordingly, some tools were very heavy, while others were light, long, short, pointy, sharp, flat, thin, flexible and even rigid depending on their function.

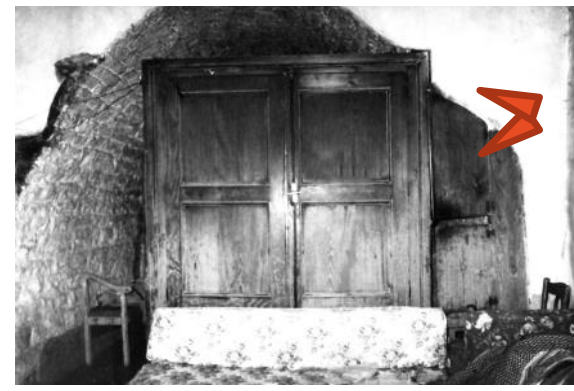

Fig. 16. my pictures: an old ' $A b o u$ ' with a small 'Youk' as inner separation

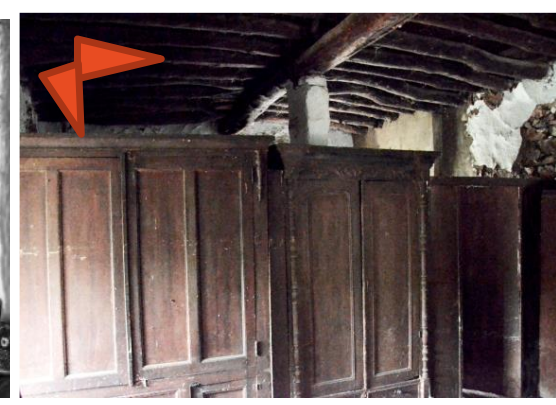

Fig. 17. ceiling made of wooden loges; 'Ousallet' with a huge old 'Youk' underneath

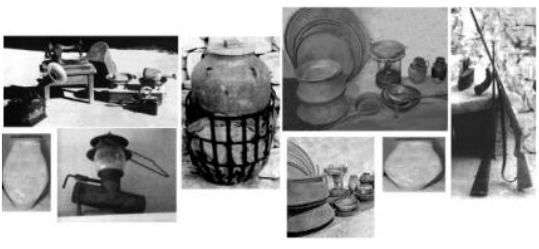

Fig. 18. some old folkloric forms and some artifact items of ancient times that were used in old houses

The carpenter worked in parallel with the mason, his role was cutting trees, preparing ceiling logs, fixing doors and windows, and constructing different basic pieces of furniture; the famous 'Youk' which was a big wooden closet, served as the only partition in the old rectangular or vaulted houses, it was used from both sides of the interior space. In some old houses, an inner wooden door was attached to the 'Youk'.

In this part, we are going to emphasis on few of these tools that were used by the mason whose main concern was to cut the huge rocks, shape them to obtain the straight piled, and strong walls for the intended house. Most of these tools were use on the outside of the 'Kalline' walls. the inside walls were not neatly cut since a layer of mud and hay should later be spread, and finally covered with white layer of natural limestone. The names of the tools vary from one village to another, all the tools were made of solid steel, strong natural yarns and hard oak wood.

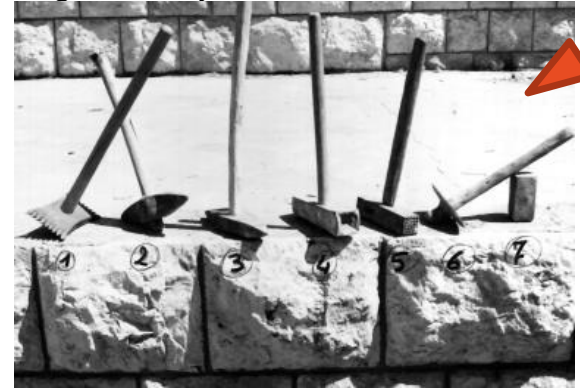

Fig. 19. showing some tools that needed the small stone 'Msan' to stay sharp

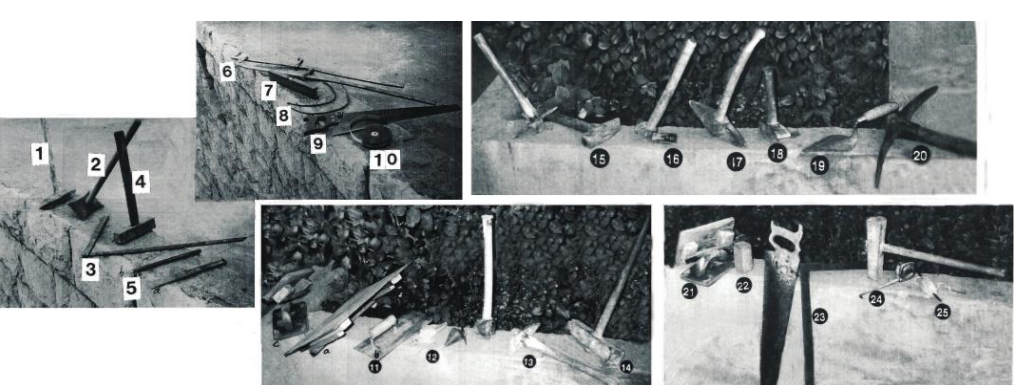

Fig. 20. my pictures of my fathers' old masonry tools; back until in the 80 s all of these tools were still in use.

Some masons were still using the traditional tools in building or renovating the traditional Lebanese house until the late twentieth century, my late father 'Maalem' Phillip, had been one of them. Unfortunately, in the twenty first century the Lebanese masons are becoming scarce, and the traditional tools are on the verge of extinction.

n. 1 'Shahhouta', used to determine and flatten the shape of the stone: square, rectangle or corner. it had two edges; one flat and the other similar to a fork

n. 2 'Beek' it had two sharp ends, used to flatten the stone from all sides and also used to flatten the stones that were used to cover the floors in the old houses 
n. 3 'Itta-aa', used to make smaller tunnels in the big rock. It had two edges; one pointed and the other flat. After making these tunnels, the 'Mhaddi' was used to strike the stone into smaller pieces

n. 4 'Shakouf', the first tool used by the mason, a big and heavy tool, used to cut roughly, pieces from the rocks

n. 5 'Boushard' or the 'Mtabbet', used to flatten the surface of the stone to the finest degree. It had one rough and another smooth edge

n. 6 'Tartbeek', a thin tool compared to the other tools with one pointed and another flat edge, used like a cutter before the 'Shahhouta'

$n$. 7 'Msan', a very important tool, sort of rectangular sandy stone, mainly 'Shahhar', used to sharpen the tools.
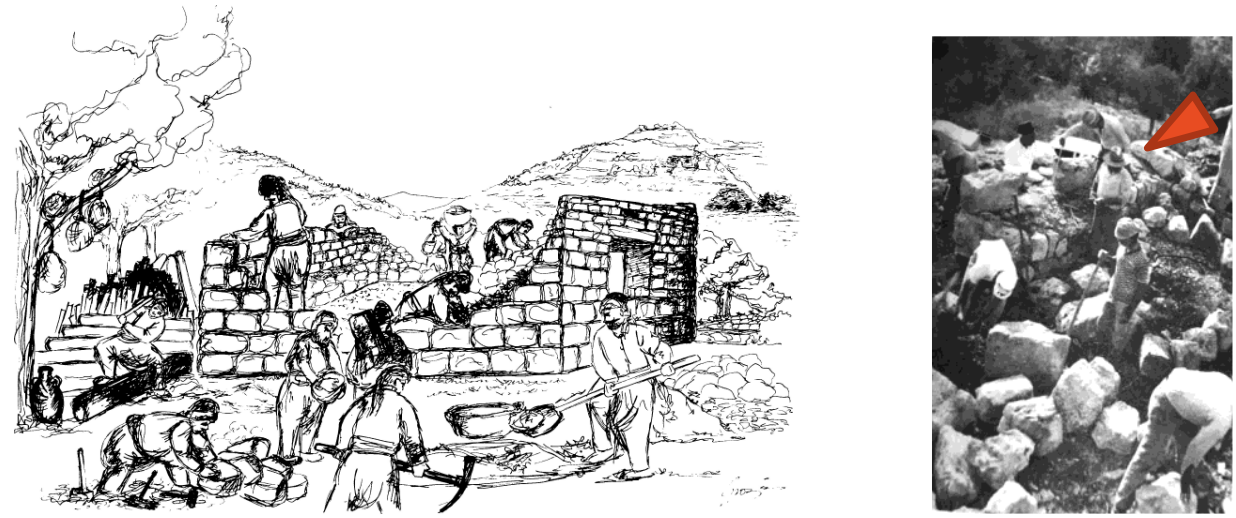

Fig. 21. My illustration showing the act of

Fig. 22. (El Khazen, 1995, p. 78) 'A-aounet' in building an old vernacular house in ancient times.

showing my father while working on reconstructing old church in the $80 \mathrm{~s}$.

My documentation started early in the 1990s. Since then, I have been trying to define what is the true concept of 'A-aounet', it was generated in the moment when men first, got together on the construction site and decided to work together and build a house for one of them. Tasks were distributed and the construction began in a harmonious system, similar to a bee hive or 'Khalliyet Nahhel'; everyone knew what to do, everyone was lending a hand, helping and working to finish the task assigned to him by 'el Ma-alem'; men were plowing, digging and straightening the land, others were carrying, cutting and carving the big rocks while others were sorting, cleansing and smoothing the stones whilst others carrying water and hay and mixing the paddings, other men were crunching smaller stones, mending and cleaning the ground for the formation and foundation of the first and most important row of large roughly cut stones.

Some of the masons' old tools were used for measurements, in both exterior and interior spaces such as; 'aashit el ma-alim', 'mezoura', 'khait el ma-alim', 'khait mizan' or 'belbol', 'zaiba-a', 'dra-a', 'beekar', 'aale-es' and 'zeouyet'. Needless to say, all these measuring tools now became obsolete. Other old tools were used for various purposes, either to hammer, cut, dig or mix also used to sharpen or flatten the stones, such as: 'siroua-a' or 'minshar', 'maadour', 'Shaouket', 'raffsh', 'addoum' 'matra-a', 'zmeel', 'Shahhouta', 'mistarine', 'melij', 'kaff' and 'mafrak' to name a few.

Every tool used in building the old traditional houses in Achkout was made from natural material, well maintained and systematically used by skilled masons. Needless to say, the drastic evolution from traditional tools to innovative machinery, pushed the vernacular house towards the verge of losing all bondage with the inherited folkloric know-how skills. Therefore, the intuitive ways of construction, and most importantly the human relationship towards family and nature within the village context is lost.
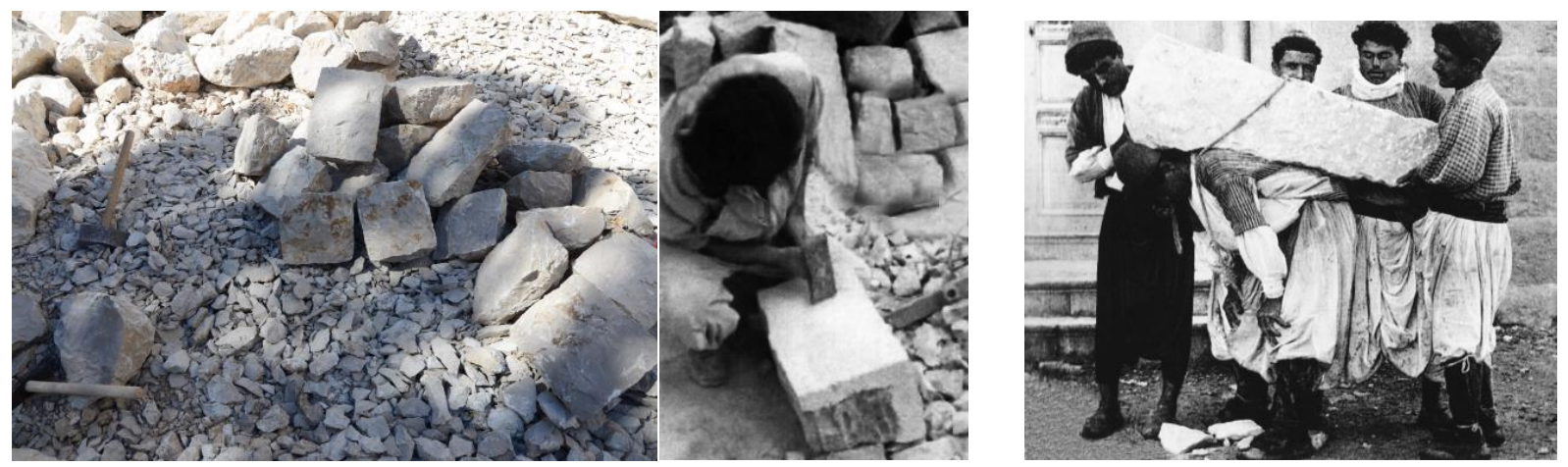
Fig. 23. My pictures: showing old masonry techniques in Fig. 24. (Acra-Raad, 1997, p. 129) renovating an old house in Achkout built in 1875, now owned by Massaad C.

\section{INTERIOR SPACE}

\subsection{Volumes and Spaces}

The traditional old houses and shelters in Achkout were modest and humble from inside out. Farmers' houses were simple but neatly built in a square or rectangular shape. Such houses were located in valleys and fields in order to be near streams and rivers; the crops needed to be watered as frequent as possible, and the farmers had to travel safely and quickly between villages. On the other hand, shelters were quickly and randomly built. Most of their stones were not carved. These hideouts looked more like dens integrated within mountain verges, where the dwellers could safely hide, and occasionally escape in case of unexpected attacks or disasters.

As families expanded, the construction started, and new houses got closer to each other, especially among family members, this created deep bonding and strong attachment towards the head of the family; grandfather, father and son, where respect, values and ethics played an important role in keeping the traditional and cultural qualities alive in every household. The formation of the interior space in the old house with its 'Dar', nowadays known as living room, permitted the development of close kinfolk relationship. Families assembled, connected, talked, laughed, played, ate and slept all in one place, that interaction founded the fundamental base of family relationship that shared, endured and survived good and bad times.

Inside these walls, long winter nights were spent telling fables and fairy tales while eating dinner around a low circular table, close to the fire under one or two lights from oil lamps or candles placed on the thick inner wall of one of the windows in the old house. (Al Kassis, 2001, pp. $101-105$ )

\subsubsection{Volumes}

The first inhabitants who settled in the mountains of Achkout lived in conventional primitive vaulted shelters 'Abou a-aed'; a single cell volume of five to eight meters long similar to one directional tunnel. The early dwellers swiftly realized that these primitive houses were not really suitable as living quarters, therefore, the function shifted to provide the perfect shelter to domestic animals, and the dweller constructed his own house above the primitive 'Abou a-aed'. The domestic animals, mainly sheep, goats, cows, and donkeys were precious and extremely important, since they provided food, milk and meat, as well as, clothes, linens and vessel to carry water 'Darf', among others. (El Khazen, 1995)

The vaults were also used as dens to store the huge clay jars 'khebiyet / khawebi', 'dakouji / dkakij' of olive oil, wine, flour and all sort of seeds and dried herbs, in other words the provision or 'mounet' that our ancestors prepared during summer time with the use of 'a-aounet' in order to consume it in winter.

The idea of the two-story houses became popular, especially next to the main old street, known as 'Karrousa'. In 1875, a small shop or 'Dikkenet' owned by Roukoz Massaad opened. It was a tiny vaulted 'Abou' situated in a strategic location along the 'Karrousa', near to the church and the village square or 'Sehhet el Daia-a'. 'Dikkenet Roukoz' had gathered all possible commercial functions, mainly coffee shop, grocery shop, barber, post office among others and was among the very first examples of a two-floor house in the region.

The connection between the two floors was mainly external, but as they started searching for convenience and security, stairs started to appear inside the old houses. This inner connection leading to the vault was secured by a door called 'Manbesh' that was extremely important during the heavy storms and thick snow.

There were two main reasons for the scattering houses to build these inner passages; peasants needed such passages in order to reach their domestic animals in winter; the ground of the vaults was made of dried earth, pressed and flattened providing warmth and coolness for the animals, and also acted as a natural filter for the dirt of the animals or 'tarsh', when they were locked in during stormy weather. On the other hand, the rich people used these passageways to reach a secret den built to hide weapons, food and money.

This adaptation of the two-floor construction method was significant since it allowed the vertical separation between the living area and the service area. In other words, terminated the cohabitation of man and animal.

\subsubsection{Old Methods in Building}

Not everyone in the village was able to build his house with clean cut stones, some of them used small rough stones, to hide these rough stones, a mixture of soil and straw was applied as a cover and once dried, it was 
painted with organic plaster. Several major elements were needed to build one house; the appropriate location, proper timing, enough cut stones, timber, wood, mud, hay and plenty of helping hands 'a-aounet', and it used to take several months to finish. We have two major types of traditional houses in Achkout, mostly inhabited by peasants, farmers or shepherds. The shapes were either in a square or rectangular vaulted form, where the height of these vaults varied between three to five meters, depending mostly on the location, while the interior design was mostly based on modesty humbleness and satisfaction in a neat and organized central space. (Bassil, 2007, p. 255)

The basic applied processes in building vaults were many depending on the personal experience of the mason, his 'a-aounet' and their expertise in using the old tools and different kinds of stones.

the oldest predominating technique used in Achkout, can be summarized as follows; the workers started by cutting the trees and placing them on top of each other to create the desired mold. Once finished, the stones were sorted, measured, cut and placed row after the other from both sides of the curve until reaching the top. The vaulted roof then was closed by the last set of 'key stones' known as 'ifl', forming a firm closure of the vault. Once the trunks of the trees were removed, the cut stones caved in and held one another in almost a perfect curve, later on a small door was created in the middle of the facade. Windows did not exist at first in the vault, but later on, a door was located at one end and a small window at the other end.

\subsubsection{Design Elements and Furniture}

Dweller in these old vernacular houses began developing shapes and pieces of furniture essential for their everyday lives. The minute they passed the threshold, while performing a humble bow, they directly step in this recessed zone called 'Madwara', where they took off and washed their rough working shoes 'Shdou', in order to put on the casual light footwear, 'Shahhata', and enter the house.

The uneven and unusual textured floorings gave each house a unique character. These floors that were covered with handmade 'Bsat', 'Hassireh', and animal skins, were perfect to keep warm and give a cozy feeling.

The most important feature would be the huge closet or 'Youk', this main furniture piece that consisted of one large store-closet, used from one side to store food for winter or 'mouni', and from the other side to pile linens and clothes, transforming the space from living room to bedroom, in a simple, nonetheless wellorganized fulsomely act of, multifunctional space use efficiency, that revealed the mastermind perpetual folkloric use of architectural forms and customs in a unpretentious manner. Moving to some smaller pieces, they used to drink using 'Bre-e', eat food that was place on 'Tabliyet' while sitting on 'Terrahha', that were filled with straw and hay. 'Andeel el Kaz' was the main source of light in the darkest nights, usually hanged on the wall. Going further inside the house, they had 'Taa-el' caused by the need of ventilation, since they used to cook inside the house. The 'Maou-adi' and 'Dist'; this large pot made of brass for cooking located close to the 'Mastabi'; a very important interior element used to raise chickens, 'Sallet Ash' used to carry fruits, 'Mda-at' and 'Jirm Kibbet' used to smash meat and different herbs like 'Zaatar' or thyme. (EI Kassis, 2001, pp. $47-69$ )
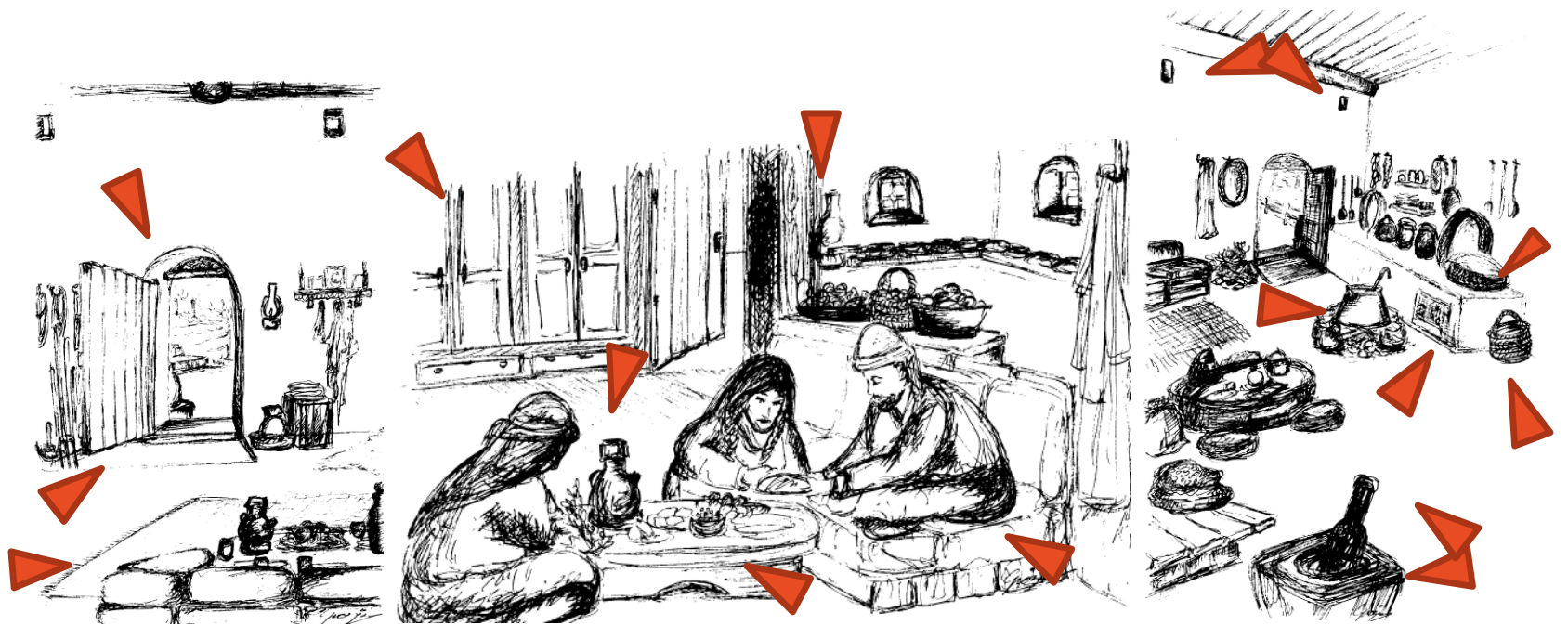

Fig. 25. My illustrations showing old domestic interior spaces and some essential pieces of furniture that dwellers used in their humble houses; 'A-atbi', 'Madwara', 'Bsat' 'Youk', 'Breek', 'Andeel Kaz', 'Tabliyet', 'Terrahha plural Traarihh', 'Ta-at', 'Maouadi' and 'Dist', 'Youk', 'Ma-ajen', 'Sallet Ash', 'Mda-at' and 'Jirn Kibbet', to show a few. 
All doors in the traditional houses of Achkout had short threshold obliging everyone to bend before entering the house, this had two purposes, first, one should bow to be able to enter the home of someone and the second, if you are carrying the traditional long riffle or sword, one cannot force his entrance while holding those weapons in case he was bending and ready to battle.

Concerning their location, doors used to be situated on both sides, one facing the, other taking into consideration three justifications; to be able to enjoy the nice wind-draft in summer, to have another exit if the snow blocked the main door in winter and finally to be used as a quick getaway in case of any raid.

As for the windows, they had very simple rectangular shape, most commonly built on the South-West or South-East sides in a way to avoid the North glacial winds. We cannot distinguish any ornamentations or decorations for the windows until lately. The only thing which was added to the windows was the iron bars from the outside and the wooden shutters from the inside; both on the exterior wall, leaving the edge of the window to be used as a shelf from the interior.

\section{CONCLUSION}

The way our ancestors behaved towards creating a shelter in Achkout and its approaches, they endured to design their interior spaces in these mountains and revealed this constant regard to mother nature. In every chore, in every act there was human ethics, values, and moral integrity. The mason who built the stone house with just few primitive tools, using only genuine methods, and humble regard and respect to both mother nature and to mankind, features that were clearly reflected, in the close bonding with nature, "from nature to earth", an old saying which meant to them, take only what you need, and live in peace with your surroundings. Is the need to build new modern house more important than building a home?

Nowadays, each stone that took so many hours of tough work to reach its final form and size, is now on the verge of total demolition. We are witnessing the destruction of our traditional old houses. This uncontrolled infusion between the past and the present in constructing and building houses in the villages, need to have a better structure in the intermixing between conventional customs, and the old ethnic performances related to the folkloric masonry of interior spaces, in a way to make us proud once more of the prestigious old houses in our mountains.

It is a shame to lose such a heritage that was a part of our history and culture. I am not saying, that in order to build a stone house, we should spend years in the making, I am just highlighting the fact that we can benefit from the Traditional Folkloric Forms and Narrations that were previously used, to set new guides towards better future designs, where the past and present coexist, and the new invention in designing stone houses would be better adapted to the nature of the mountains of Achkout; eco-friendly, sustainable and recyclable, and more correct regarding the folkloric legacy of building, reserving and reviving our traditions.

Finally, the old gathering and helpfulness act called 'a-aounet' that used to engage many people, made them feel useful, and creates the feeling of satisfaction and caused a joyful celebration to all who worked on site, that 'a-aounet' does not exist anymore...

After all, is it not human achievements to satisfy human Needs?

"Architecture is a conscious process, which conceptualizes Platonic Forms into spatio-temporal entities, in conformity with the contemporary paradigm (epistemological, ontological, teleological and methodological dimensions), to satisfy Human Needs". (Younes, 2009, pp. 15-19).

\section{REFERENCE LIST}

Abou Al Ainain, H. S. (1980). دار النهضة العربية ,لبنان دراسة في الجغر افيا الطبيعية

Acra-Raad, P. (1997). Une Montagne et des Hommes

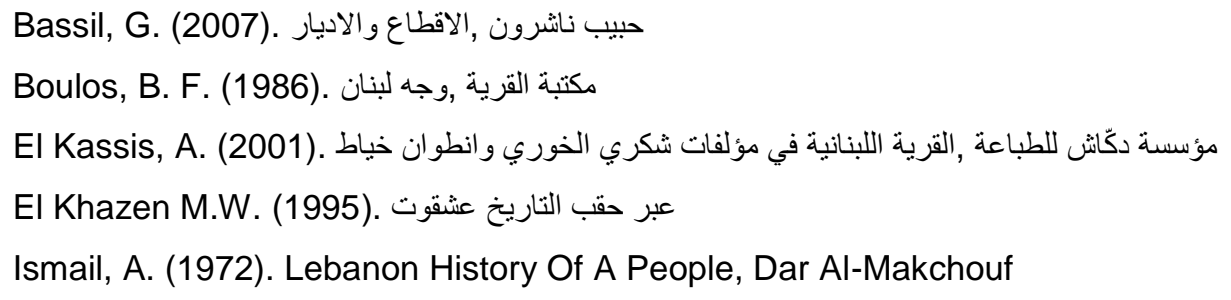


Khater, L. (1977). مطبعة الجبل, العادات و التقاليد اللبنانية, vol. 1 and 2

Makki, R. T. (1995). المؤسسة الجامعية للار اسات و النشر والتوزيع ,مقاربة نفس - إجتماعية للمجال السكني

Map data (2018). Google, ORION-ME

Maroun Abboud, M. (2012). مؤسسة هنداوي للتعليم و الثقافة ,احاديث القرية

Massaad, A. (2014). بين قلاع عشقوت وتلال اندريمون

Ragette, F. (1974) ARCHITECTURE IN LEBANON, The Lebanese House During the $18^{\text {th }}$ and $19^{\text {th }}$ Centuries, CARAVAN BOOKS

Younes, F. (2009). What is Architecture, Lebanese University, Institute of Fine-Arts, issue n: 14 \& 15, Lebanese University Institute of Fine-Arts. 